DOI https://doi.org/10.18551/rjoas.2018-05.24

\title{
THE CONSTRUCTION OF SHARIA MANAGEMENT ACCOUNTING OBJECTIVES: REACHING LIQAA-A RABB AND MAQASHID SYARIAH
}

\author{
Sonhaji \\ STIE Malangkuçeçwara \& Doctoral Program, Faculty of Economics and Business, \\ University of Brawijaya, Indonesia
}

Triyuwono Iwan, Djamhuri Ali, Mulawarman Aji Dedi

Faculty of Economics and Business, University of Brawijaya, Indonesia

*E-mail: sonhaji60@gmail.com

\begin{abstract}
This study aims to construct the concept of Sharia Management Accounting (ShMA) objectives as an alternative to the conventional Management Accounting whose values are not always compatible with Moslem entrepreneurs. The Entrepreneurs need an information system which contains Islamic values namely ShMA. This study uses a qualitative approach through data identified from Islamic values from studying the Qur'an, hadiths and other Islamic literatures as well as interviews with informants. Under zikr, prayer, contemplation and analytical methods researchers come into a construction that the objectives of ShMA are essentially to help assist entrepreneurs in the provision and use of information that can allow to achieve the ultimate goals of life, namely liqaa-a rabb ("meeting" with God) and operational objectives of moamalah, maqashid syariah (sharia objective).
\end{abstract}

\section{KEY WORDS}

Management, accounting, Sharia, Liqaa-a rabb, Maqashid Syariah.

This study deals with the objectives of Sharia Management Accounting (ShMA) or concretely to answer the question what are the objectives of ShMA for further development? Compared to sharia-based financial accounting practices, ShMA is less prevalent. Previous studies proposed the techniques of management accounting (MA) in the perspective of Islam to determine the best method to apply (Abdul-Baki, Uthman, Olanrewaju, \& Ibrahim, 2013). Another study was conducted to review the information obtained from the MA system in both conventional and sharia-based financial institution (Rasid, Rahman, \& Ismail, 2011). However, their ideas had not yet tapped on the specific insights in constructing the objectives of ShMA. This concept is regarded as the key point in determining the orientation of the development and the practice of ShMA. The objectives and the direction of MA and ShMA are slightly different which urged the researchers to identify the real intentions of ShMA.

The history of MA has started since the 18 century, and MA has been growing in line with the growth of science and business (Juras, 2014; Kaplan, 1984; Waweru, 2010). At present, MA has been quite useful for business operational necessities. MA holds a vital role in simple practices up to strategic of business (Ferrara, 2007). Similar to other types of accounting, MA has two effects toward the environment in which MA is formed by the environment, and it creates the environment at the same time (Triyuwono, 2000). The intensive interaction allows MA to give the significant contribution to any users' behavioral changes (Covaleski, Evans, Luft, \& Shields, 2003). Thus, MA as a body of knowledge and as a practice is always bounded to certain values (Triyuwono, 2004, 2006). Consequently, MA appears as a facility which implementation is influenced by certain values in it.

Seen from the evolution, it can be said that MA developed on the basis of WesternModern values since MA rapidly grows in western countries (Triyuwono, 2004, 2006). Internalization of certain values is a normal process as the result of the advancement of science (technology), and it brings specific characteristics as stated by Sardar (1998) that technology carries values from the place of origin which might be transferred to where it is 
applied. Western-modern science and knowledge has been known to solve various problems, but claims for its advantages do not diminish its weaknesses, whose fundamental values do not always correspond to their place of application, as in the Islamic community. As the part of the system of information in a company, MA holds a key role. The MA is in the practice of human greed in running a business, so preferably MA function to prevent people from the effects of harmful characters.

Regarding its role, MA ideally is modified by internalizing other values that are generated by the third eye or as referred by "Sé Laén" ("Sing Liyan," the Others) as "the deconstruction of the intellectual center" (Triyuwono, 2010) which was implemented by as the adoption of Islamic values. Exploration of Islamic values in sharia accounting has always been an exciting topic to discuss. This exploration should be continually implemented to find the best practice (Velayutham, 2014). This kind of review is done in the financial accounting (FA) context, yet it has not yet administered in the MA context. To grow with the developing of sharia accounting studies, the MA ideally also adapt concerning knowledge and practice.

As previously stated, this article seeks to establish the concept of ShMA's objectives for its further development. The focus of this study is to formulate the objectives of ShMA. The method of the study is given in the next section, while the characteristics, functions, position and the effect of ShMA are presented in the following sections. This article is closed by the explanation of ShMA objectives as the base of its development.

\section{METHODS OF RESEARCH}

This study is administered under qualitative approach based on Islamic Spirituality. Data are identified from Islamic values through a reading of texts from the Qur'an, hadiths and other Islamic literature as well as interviews with informants and analyzed through the method of zikr, prayer and contemplation (ZPC), and analytical method. This ZPC method was introduced and being developed by Abdurahim, Triyuwono, Mulawarman, and Achsin (2016) and Triyuwono (2015). Zikr and prayer are the forms of vertical relationship between human and God. Both zikr and prayer are done to remember the presence of Allah through intensive interaction. However, zikr and prayer are different. Zikr refers to spoken, physical and emotional activities that close the distance between human and God (Dasuki, 1994a). Zikr is done by reciting Allah's names (Asmaa al Husnaa) and vowing to Allah as the one and only God. Zikr is better done in the morning and evening as often as possible ${ }^{1}$. Through zikr, the human asks for hopes and ability to receive goodness from God.

Prayers are words sent by a human to ask for hopes and to worship Allah SWT in a certain way. Prayer contains requests, expectations, greetings, and compliments to Allah SWT (Dasuki, 1994a). Prayer also gets the human to stay close to the God by telling their requests and hopes. Prayer and requests are directed only to Allah SWT, as the only God who holds the highest power in granting human's wishes ${ }^{2}$. Besides using the way of praying as taught in the Qur'an and Hadith, Moslems may create their own prayer to ask for certain things to the God.

Contemplation (tafakur) refers to the activity of deep thinking, contemplating, or meditating. Tafakur is suggested by Qur'an for a human to deeply think about Allah SWT's creation (Dasuki, 1994b). Tafakur is a solemn activity by engaging in dialogue between information obtained from thoughts and feelings with those of the Qur'an and Hadith (Abdurahim et al., 2016). In the context of this study, tafakur is included in the prayer and zikr. Thus, the use of a way of thinking that leads to the awareness of the Godhead is a form of reflection ideally integrated with zikr and prayer.

\footnotetext{
Recitation of Qur'an from Al-Huda (2014).

Surah Ar-Rad (13) verse 28: "Those who believe (in the Oneness of Allah - Islamic Monotheism), and Whose hearts find rest in the remembrance of Allah. Verily, in the remembrance of Allah do hearts find rest".

Surah Al-Ahzaab (33) verse 41: "O you who believe! Remember Allah with much remembrance".

2 Surah Al-Faatihah (1) verse 5: "You (Alone) we worship, and you (Alone) we ask for help (for each and everything)", and QS Al-Baqarah (2) verse 186: "And when may slaves ask you (O Muhammad saw) concerning Me, then (answer them), I am indeed near (to them by My Knowledge). I respond to the invocation of the supplicant when he calls on Me (without any mediator or intercessor). So let them obey Me and believe in Me, so that they may be led aright".
} 
The data of this study are in the forms of texts or lesson recited from Qur'an, hadith and Khabar Sodiq (good and true news) which were systematically documented (Islamia, 2005), and results of interviews with informants. The collected data are then analyzed using an analytical and reflective approach (Velayutham, 2014). ZDT is a method throughout this study along with qualitative research activities as stated by Huberman and Miles (2009) such as data collection, data reduction, data presentation, and decision making.

This study employs the flexibility of the qualitative approach which allows the researchers to develop an appropriate design to meet the need of this study (Moleong, 2005). The chosen method allowes the researchers to act as the primary instrument in the data analysis by conducting analytic and reflective activities. The researchers also attempt to review the most appropriate objectives of ShMA that matched the values of Islam. Through the intensiveness of ZDT, reflection and analytic action, the researchers attempted at capturing verses from Qur'an, Hadith, and Khabar Sodiq that match the objectives of ShMA. When the researchers find one, the verse is then compared to the definition of ShMA. Later, the researchers take certain actions to determine the usability of the data to answer the research questions of this study. Therefore, it is necessary to explore the definition of ShMA before administering the analytical discussion.

\section{RESULTS AND DISCUSSION}

Definition of ShMA. According to the main idea of this study, ShMA refers to the transformation of MA. The concept of ShMA arose from the needs of an MA information system with good compatibility toward Islamic values and sharia rules to fit the need of Moslems in managing and running their business and organizations. ShMA holds an essential role because it can create particular method or technique that regard "internalized Islamic values" which are expected to influence users' behavior. The most interesting question is "is ShMA completely different from MA?". A broad discussion on the dominant concept of MA and its technical implementation from Islam point of view was necessary to conduct. Explanation of the definition of ShMA adopted from Sonhaji (2016) is presented before the discussion session.

Before defining ShMA, it is necessary to determine the definition of MA to see the development of MA orientation. Two descriptions of MA show the change of MA overtime. The National Association of Accountants (NAA) defines MA as follows.

Management accounting is the process within an organization that provides information used by an organization's managers in planning, implementing, and controlling the organization's activities. This process includes the identification, measurement, accumulation, analysis, preparation, interpretation, and communication of the information needed by management to perform its function (Anthony \& Reece, 1989, p. 515).

An important point from the definition shows that management does not face complex competitions for it should only do the tasks based on its function. Different from the definition stated by the Institute of Management Accountants (IMA).

Management accounting as value adding improvement process of planning, measuring and operating nonfinancial and financial information system that guides management action, motivates behavior, and supports and creates the cultural values necessary to achieve an organization's strategic, tactical and operating objectives. (Atkinson, Banker, Kaplan, \& Young, 1995, p. 5).

An environment is ever-changing, leaving only companies which are able to offer extra values to the customers that will survive and win the competition. The MA definition of the IMA indicates the difference of emphasis and orientation of the MA on changes in management. The orientation is also presented by Hansen and Mowen (2005) whose definitions include customer orientation, strategic position, and Value Chain Framework. Concerning this value, there has been a shift in the MA from the value-added concept to value-creating activities (Shank \& Govindarajan, 2000).

Related to the managerial necessities as presented by definition above, MA has fulfilled the concept based on its function. There is the shift of the orientation reached from 
the cost analysis to the value-creating activities. MA is characterized by material-financial orientation and has not yet tapped on any transcendental or worshipping activities which are Moslems necessities. An important question arose, "can MA be made oriented to worship?"

A Moslem is required to orientate any action to Allah SWT. This is in line with Allah's command stated in Surah Adz-Dzaariyaat (51) verse 56: "And (Allah) created not the jinns and humans except they should worship Me (Alone)." This value is emphasized in the Hadith which states that "actions are based on intentions, and everyone will get what was intended" (Amir, 1974). In the context of Islam, those who only do any activities without orienting it to worship the God are losing. Therefore, the development and the implementation of ShMA is ideally intended to worship Allah SWT. Therefore, the answer to the question in the previous paragraph is definitely possible. MA which is transformed on the basis of Islamic values is called ShMA.

The function and the objectives of sharia accounting that have been previously proposed can be used to define ShMA. Some academics have stated their insights that sharia accounting is "...as an instrument of prayer and remembering God for awakening God-consciousness" (Triyuwono, 2012). According to Lewis (2001):"Accounting, if performed in accordance with Islamic law (the sharia), should be as much an act of worship and prayer." Also, according to Mulawarman (2011, p. 201), sharia accounting better has the main orientation "as the realization of humans' love for Allah SWT".

Considering the roles of MA within the value chain process in the form of value-creating activities and the characteristics of sharia accounting, the researchers defines ShMA as a set of knowledge and practical guidance to create information of any process within a network of values to implement Islamic values as zikr dan prayer to fulfill economic, mental, and spiritual necessities as the form of worshipping the God. This definition puts ShMA in the practice of commercial activities and business to enhance the values, expanding economic and trade activities beyond financial orientation and more on spiritual-transcendental worship activities. ShMA is also a way to show love for Allah SWT and an attempt to approach the God. Hence, it is clear that the difference between MA and ShMA relies on the presence of spiritual orientation, yet both of them intend to provide useful information for users.

Based on the definition, ShMA has a broader role beyond financial-material oriented activities. Allah's commandment related to this matter is written in Surah Al Maidah (5) verse 35: "O you who believe! Do your duty to Allah and fear Him. Seek the means of approach to $\mathrm{Him}$, and strive hard in His Cause as much as you can. So That you may be successful". It is true that there are many ways to show faith to Allah and there are various ways to strive for the religion, which one of them can be done by implementing the ShMA. Therefore, the word "be successful" refers to both fortunes in life and afterlife ideally underlies the development of ShMA. This point is the main objective of ShMA.

Function, Position, and Influence of ShMA

Regarding to the definitions that have been previously mentioned, MA and ShMA as an information system in an organization, both of them have similarities function including; (1) providing information based on a management process from the planning to controlling in order to make sure that the management runs its function well, (2) providing information based on the identity of the senders to be distributed to the correct receivers, (3) providing information based on structural organization hierarchy including the top management, middle management and operational management, and (4) enhancing the internalization of cultural values and other good values in any organizational activities from suppliers' activities to customer handling and the information system. Meanwhile, the difference between MA and ShMA relies on the function of ShMA that taps on the objective to obtain material-economic benefits as well as spiritual benefits in the form of prayer, zikr and taqarrub (draw near to Allah). This can be considered as the fifth characteristic of ShMA.

From the explanation of the characteristics of MA and ShMA, it can be concluded that ShMA is an information system that holds broader functions, positions, and influences. The attributes of ShMA is illustrated in Figure 1.

It can be inferred from the figure that: (1) ShMA should be able to cover the information reporting in the whole process both intern and extern value networking. In the internal 
network, ShMA prepares and report the intended information that fits the needs of the top management, middle management, and operational management. Meanwhile, in the extern domain, ShMA should arrange and report information related to suppliers and customers. The information is adapted to the characteristics of ShMA itself. (2) ShMA creates value networks and presents information according to the needs of the units within the organization. (3) ShMA as a tool that helps a company running its organization should be able to create and provide information related to the function of management from the planning, decision making, up to the controlling process. (4) The function of ShMA as a tool to reach both material-economic objectives and spiritual objectives through prayer, zikir and taqarrub to Allah SWT.

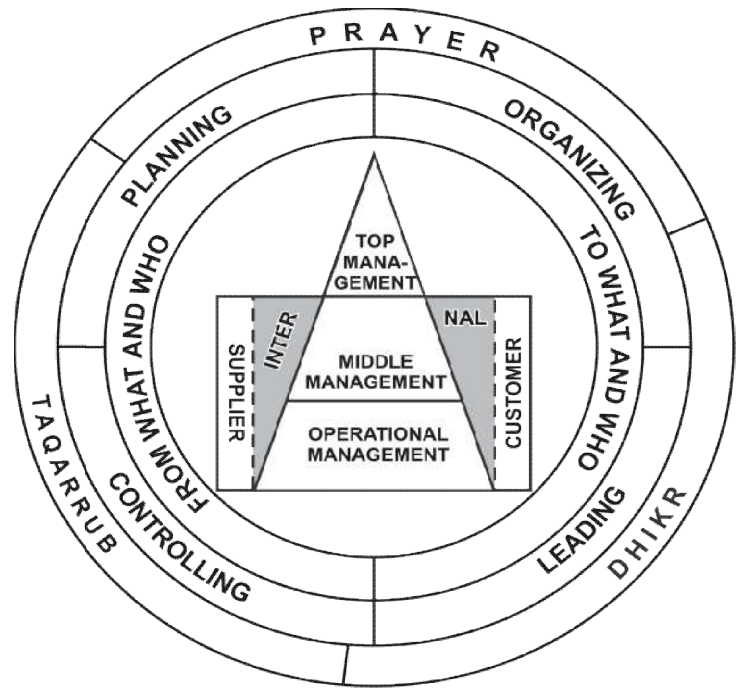

Figure 1 - Scope and Function of ShMA

In another word, ShMA covers quantitative and qualitative information as well as financial-material and transcendental objectives which development and application are done to reach life and after-life dimensions. ShMA is expected to facilitate people in business to run business based on Islamic values. ShMA ideally influences people to modify their behavior and to get them direct their activities to worship the God. An important question that needs to be answered is what is the real objectives of ShMA related to its function and scope of effect as stated above?

Liqaa-a Rabb: The Highest Objective of ShMA

Before answering the question related to the objectives of ShMA, it is necessary to explain question related to whom ShMA is for. The answer to this question determines the goals of ShMA. It is obvious that ShMA is a facility that helps an organization to reach its objectives or the objectives of the organization's main participants. It implies that ShMA is meant to help a human. Therefore, objectives of ShMA are ideally no different or contrary to the ultimate objective of human beings. If ShMA is built on the basis on Islamic values, then to know the ultimate goal of humanity should also be based on Islamic perspective.

Outside Islamic context, there are two perspectives on the creation of human; pessimistic perspective and optimistic perspective. These two attitudes have different and contradictive basic concept of life. Pessimistic outlook views life negatively without any meaning or objectives. Meanwhile, the optimistic perspective believers consider life precious and worth fighting for. They are motivated to work hard to reach happiness in life. Thus, life from the optimistic perspective is full of meaning and goals (Madjid, 1992). The objectives of life are entirely subjective since they are determined by what makes a person feel happy.

Within the Islamic context, Islam rejects the pessimistic perspective since it goes contradictory to the concept of Islam as the religion of love for the universe. Moreover, Islam believers are forbidden to have a pessimistic attitude about life. Meanwhile, Islam does not 
reject the optimistic perspective that believes life has specific meaning and worth fighting for. A question appears related to what kind of meaning and where it should direct.

This question is critical to be answered since it is strongly related to the real goal of the creation of human and its goals. This issue has been an exciting topic to discuss among philosophers. They have been trying to figure out the meaning and the objectives of the creation of humanity in the world. The real intention of human creation has been an interesting issue to discuss among philosophers since the answer is the basic theory of any knowledge. Philosophers see human from various perspectives including the biology, philosophy, and myths (Fidiana, 2016). Hence, it is normal to have different perspectives about life because the debate has not yet found an agreement. Therefore, in Islam, the objectives of life should be matched with the information and commands given by Allah SWT.

A good Moslem should be able to understand the concept of life to understand the real objective of life by studying Qur'an. The clear aim of life as stated in Qur'an and has been agreed by Moslems is the Liqaa-a rabb or "meeting" with God (Madjid, 1992, p. 18) which verse states:

Say (O Muhammad saw): "I am only a man like you. It has been inspired to me that your llâh (God) is One llâh (God) i.e., Allâh). So whoever hopes for the meeting with his Lord, let him work righteousness and associate none as a partner in the worship of his Lord" (Surah Al Kahfi/18: verse 110).

Related to this top goal, an informant pointed out a relatable verse as stated below.

It is true that liqaa-a rabb should be set as the top goal of life...it has to be the biggest dream in life...but there are some relatable verses besides Al Kahf (18) that is the verse 110 [while opening the translated Qur'an, informant shows his letters by reciting his verse].

In relation to the "meeting" with Allah, some other verses provide insights on this matter, such as.

And send (good deeds or ask to Allâh bestow upon you pious offspring) before you for your own selves. And fear Allâh, and know that you are to meet Him (in the Hereafter), and give good tidings to the believers (O Muhammad saw). (Al Baqarah/2: verse 223).

"O man! Verily, you are returning towards your Lord with your deeds and actions (good or bad), a sure returning, so you will meet (i.e. the result of your deeds which you did)" (Al Insyiqaaq/84: verse 6).

To obtain a better understanding about liqaa-a rabb, the researchers recited some other verses as suggested by the informant.

"The Day whereon neither wealth nor sons will avail.

Except him who brings to Allâh a clean heart [clean from Shirk (polytheism) and Nifâq (hypocrisy)] “(QS Asy Syu'araa' (26): verse 88-89)

"And, verily, among those who followed his [nûh's (Noah)] way (Islâmic Monotheism) was Ibrahim (Abraham).

When he came to his Lord with a pure heart" (QS Ash Shaffaat (37): verse 83-84)

In Surah Al Kahf (18): verse 110, Allah SWT shows how to reach liqaa-a rabb by doing good actions and believing to no other God but Allah. Related to the verse in which it is stated "and let him not associate anyone with Him in the worship of his Lord," the informant explained that this verse emphasizes on the Tawheed. Further, in the interview, the informant shared broader explanation on the relationship between this verse and the concept of sincerity as presented below.

Do not worship anyone but Allah...do not do shirk actions... and what we have talked about tapping on the concept of sincerity.... a verse might have a broader scope...wala yusrik, the following words...leads to something... it is important to notice that wala yusrik bi ibadati refer to the shirk in worship activities... yes, any act of worship should be sincerely directed to Allah. The command to always be sincere in worshipping the Lord are stated in some verses...such as in Surah Al Bayyinah verse 5... [informant recited the verse]... it can be implied that human is required to only worship Allah as the only God by purifying their intention... which can be realized in the form of sincerity in worshipping Allah. ${ }^{3}$

\footnotetext{
${ }^{3}$ The commandment is stated in Surah Al Bayyinah (98), ayat 5.
} 
In Surah Al Baqarah (2)" verse 223, Allah states that good deeds come back to the doers (and for others), and those who have faith in Allah will eventually meet Allah. Allah SWT also mentions in Surah Asy Syu'araa (26) verse 89 and Ash Shaffaat (37) verse 84 that those who have a good heart and pure heart (salîm) are given chances to meet Allah. Thus, to be given a chance to "meet" with God, ideally, one do good deeds, not worshipping other God, doing good things for herself/himself (and others) and having faith (taqwa). "The meeting" with Allah should be the highest dream of Moslems. The prophet Muhammad saw highlighted that "those who love to meet with Allah, Allah loves to meet them and those who do not, Allah hates meeting them" (Al-Huda, 2014, p. 1394). If the message is followed, Allah SWT guarantees the meeting4.

As the goal of life, liqaa-a rabb gives absolute meaning to the life of a Moslem and inspiration for all his activities. The goal should be the orientation of Moslem activities. All of Moslem activities should be oriented at Allah in the form of worship, or moamalah. Reaching liqaa-a rabb for Moslem always be pursued in moamalah one of them through the help of ShMA. Thus, ShMA ideally aims to help entrepreneurs in the provision and use of information that lead them to achieve the ultimate life goals, namely liqaa-a rabb ("meet" God).

Worshipping Allah is a way to praise Allah. In the broader scope, worship can be realized in any activities which are intended to gain love from Allah. Allah the Almighty is always watching human, but most of the time, humans are not aware of it. The notification from The prophet Muhammad saw above ideally can be an inspiration in doing moamalah that ShMA can help grow this awareness. This way, ShMA will have stronger influence toward the behavior of the users in directing their intention in doing any activities to meet Allah. Within this condition, ShMA is not merely a material-financial effort, but it also appears as a transcendental action which is oriented at the life and the afterlife.

The ultimate goal in life should be realized into real action as in doing business. In running their business, Moslem should orientate their effort to reach the liqaa-a rabb by doing good deeds, being sincere, salîm and having strong faith (taqwa). The development of ShMA in the future ideally also regards the objectives and the ways to reach it. It can be explored from elaboration and interpretation of the ideal concepts into the method and the technique of ShMA, which are expected to encourage user behavior that is compatible with existing values. This should be ideally guided by the moamalah's objective, namely maqashid syariah (sharia goal).

\section{Maqashid Syariah ${ }^{5}$ : Operational Goals of ShMA}

Any kinds of activities done by Moslems can be regarded as worshipping the God. Every Moslem should recognize this. In Islam, there are two types of worship called maghdah and ghairu maghdah. Maghdah worship is directly directed to Allah. Activities of this worship should be written in certain commandment and based on the examples which have been provided by The prophet Muhammad saw, besides it is rather supra-rational and the primary goal is the obedience. The example of this worship is the command to do prayer and Hajj (Shiddieq, 2008).

Ghairu mahdhah worship is beyond the direct relationship with only Allah, but it is also a relationship between human and other creatures. This worship does not require commandments, but it is determined by the absence of any prohibition in doing certain actions. How to worship does not stick to the examples given by The Prophet Muhammad saw, it rather requires rationality and the principle of "benefit". For example education, work, and teaching (Shiddieq, 2008). These activities are called moamalah. The most important thing of moamalah is the intention. The intention of doing those actions determine the value of the activities either they are regarded as worship activities. On the other hand, those activities would not be regarded a good deed if the intention is not directed at Allah.

The development of ShMA is included in the domain of ghairu mahdhah or moamalah. Because of the nature of the activity and its arrangement in sharia, ideally moamalah refers

\footnotetext{
${ }^{4}$ Allah stated in Surah Ar-Ra'd (13), verse 2 about nature and science

${ }^{5}$ Maqashid Syariah is objectives of sharia.
} 
to the objectives of sharia or maqashid syariah. Thus, the objective of the development of ShMA is better derived from the goals of sharia or maqashid syariah. This concept appears following the determination of sharia law. In addition, this concept also should be regarded in determining any sharia action such as ShMA. The real meaning of maqashid syariah can be explained by the meaning of the word maqashid and syariah. Maqashid means intentional or direction. Meanwhile, syariah means the "road to the water source" which also means the route to the life sources (Bakri, 1996). Based on its definition, sharia is the laws given by Allah for human are intended to give them happiness in life and in after life (Bakri, 1996, p. 63). Therefore, there is no doubt that sharia is the best way of life according to Allah's rules.

The essence of maqashid syariah is maslahah, as one of the sharia objectives (Bakri, 1996; Syaputra et al., 2014). Maslahah is derived from Arabic which means goodness, benefit, appropriateness, properness, obedience, and interest (Asmawi, 2012; Syamsul, 2012). The term maslahah is often compared with the term al-mafsadah or al-madarrah which mean damage (Asmawi, 2012). Thus, beneficial goodness is the core essence of maslahah.

Explanation on the idea of sharia cannot be separated apart from the term maqashid syariah as mentioned by an informant.

Society cannot be separated apart from maqashid syariah...which essence is about maslahah. There are some ulama (Moslem scholars) who classify maqashid syariah into general one and special one. The general maqashid syariah refers to the whole application of intention and the goal of sharia in the entire Islamic law system, which emphasizes on the maslahah. It can be implied that the direction of sharia law is the maslahah. Maslahah has two objectives, obtaining benefits and rejecting bad things. In another word, it requires human to do good deeds and avoid doing bad things.

Further explanation on the term maslahah refers to the insights proposed by $\mathrm{AL}$ Ghazali. Maslahah emphasizes on the effort to care for, realize and to take benefit from avoidance of doing bad things to keep life directed to performs Islamic values. Maslahah should be able to maintain and preserves or maintains the five pillars of life are: religion (hifz al-din), life (hifz al-nafs), intelect (hifz al-aql), progeny (hifz al-nasl) and property (hifz al-mal) (Asmawi, 2012; Syamsul, 2012; Syaputra et al., 2014). Hence, any action that is directed at improving those five pillars is regarded as maslahah (Bakri, 1996), including any actions which attempt at avoiding bad things and negative impacts. Basically, maslahah refers to any goodness and benefits offered by Allah for the human by doing good deeds.

The results of this study show that ShMA intends to help the entrepreneurs in the provision and use of information that can encourage them to achieve of the ultimate life objective, namely liqaa-a rabb ("meeting" with God) and operational objectives of moamalah, namely maqashid syariah (sharia objective). The objective in reaching a liqaa-a rabb needs to be operational through maqashid syariah whose essence is maslahah by preserving the five pillars of life. Maqashid syariah preferably also inspires and directs companies' activities to stay on the right track with using the methods and techniques of ShMA are expected to be able to encourage entrepreneurs to achieve maqashid syariah that focus on maslahah completely.

Furthermore, the implementations of reaching liqaa-a rabb and maqashid syariah influence other goals, which the basic concept can be identified from Islamic values for the development of ShMA. Further research and discussions are expected to develop the ShMA by identifying its concept and principles and creating methods and techniques of ShMA are hoped to inspire and encourage entrepreneurs to perform its functions according to Islamic values that ultimately can achieve their ultimate goals.

\section{CONCLUSION}

Both as knowledge and as practices, MA has been developing based on westernmodern values, which are often incompatible with Islamic values. Apart from its contribution to the problem solving in the world, western-modern values suffer from some weaknesses. MA as an information system has been employed in various companies. As the part of the 
information system in a company, MA is often used, as a tool to satisfy human's ambition in running their business. Unfortunately, MA contains no values that protect humanity from the negative nature. Therefore, MA requires another value in the form of the Third Eye or Sé Laén (Sing Liyan, the Others). This leads to consequences for the development of ShMA, which can start from the idea of the objectives of ShMA.

Through ZPC method, this study collects data in the form of texts related to commandments in Qur'an, Hadith, and Khabar Shodiq, as well as data from informants to elaborate this issue. The obtained data are selected to leave only the data, which are relatable to the definition of ShMA. The data are analyzed by using an analytic and reflection method self as main analysis tool.

The result of this study shows the importance of implementing ShMA as a system of information that is compatible with Islamic values. From the study, the researchers come into a conclusion that the objectives of ShMA are to assist entrepreneurs in the provision and use of information that could lead to the achievement of ultimate life goals, namely liqaa-a rabb. At the operational level in the form of methods and techniques, ShMA preferably is able to help the user achieve the operational goal of moamalah, namely maqashid syariah that focus on maslahah. The result and idea in this article can be used as a guide for ShMA development, and subsequent researchers are better include analysis of classical "Islamic" economic literature and consider the data on sharia-compliant business practices.

\section{REFERENCES}

1. Abdul-Baki, Z., Uthman, A. B., Olanrewaju, A. A., \& Ibrahim, S. A. (2013). Islamic Perspective of Management Accounting Decision Making Techniques. Journal of Islamic Accounting and Business Research, 4(2), 203 - 219. doi: 10.1108/JIABR-05-2012-0031

2. Abdurahim, A., Triyuwono, I., Mulawarman, A. D., \& Achsin, M. (2016). Aminullah: Revealing the Spiritual Values in Sharia Transaction. International Journal of Management and Administrative Sciences (IJMAS), 4(01), 65-73.

3. Al-Huda. (2014). The Noble Qur'an. Jakarta: Al-Huda.

4. Amir, D. (1974). Hadist Arba'in: Terjemah Bahasa Indonesia. Surabaya: Salim Nabhan.

5. Anthony, R. N., \& Reece, J. S. (1989). Accounting: Text and Cases (8 ed.). Tokyo: Richard D. Irwin, Inc.

6. Asmawi. (2012). Memahami Konsep Maslahah Sebagai Inti Maqasid Al-Syariah. Paper presented at the Workshop Tafsir Asnâf Zakat Kontemporer, Ciputat.

7. Atkinson, A. A., Banker, R. D., Kaplan, R. S., \& Young, S. M. (1995). Management Accounting ( 3 ed.). New Jersey: Prentice Hall International, Inc.

8. Bakri, A. J. (1996). Konsep Maqashid Syari'ah: Menurut Al_Syatibi. Jakarta: Raja Grafindo Persada.

9. Covaleski, M. A., Evans, J. H., Luft, J. L., \& Shields, M. D. (2003). Budgeting Research: Three Theoretical Perspectives and Criteria for Selective Integration. JOURNAL OF MANAGEMENT ACCOUNTING RESEARCH, 15, 3-49.

10. Dasuki, H. (1994a) Ensiklopedi Islam (Vol. 5, pp. 2-347). Jakarta: Ichtiar Baru Van Hoeve.

11. Dasuki, H. (1994b) Ensiklopedi Islam (Vol. 1, pp. 2-336). Jakarta: Ichtiar Baru Van Hoeve.

12. Ferrara, W. L. (2007). Management Accounting: The 21st Century Paradigm. In S. M. Young (Ed.), Reading in Management Accounting (5 ed., pp. 2-9). New Jersey: Pearson Education, Inc.

13. Hansen, D. R., \& Mowen, M. M. (2005). Management Accounting (7th ed.). New Jersey: Thomson Wadsworth.

14. Huberman, A. M., \& Miles, M. B. (2009). Manajemen Data dan Metode Analisis (Dariyatno, B. S. Fata, Abi \& J. Rinaldi, Trans.). In N. K. Denzin \& Y. S. Lincoln (Eds.), Handbook of Qualitative Research (pp. 591-612). Yogyakarta: Pustaka Pelajar.

15. Islamia. (2005, April - Juni ). Pengantar: Epistemologi dalam Pemikiran Islam. Islamia: Majalah Pemikiran dan Peradaban Islam Thn II No. 5, 1-119. 
16. Juras, A. (2014). Strategic Management Accounting - What Is the Current State of the Concept? Economy Transdisciplinarity Cognition, 17(2), 76-83.

17. Kaplan, R. S. (1984). The Evolution of Management Accounting. The Accounting Review, LIX(3), 390-418.

18. Lewis, M. K. (2001). Islam and Accounting. Accounting Forum, 25(2).

19. Madjid, N. (1992). Islam Doktrin dan Peradaban: Sebuah Telaah Kritis tentang Masalah Keimanan, Kemanusiaan, dan Kemoderenan. Jakarta Yayasan Wakaf Paramadina.

20. Moleong, L. J. (2005). Metodologi Penelitian Kualitatif. Bandung: Remaja Rosdakarya.

21. Rasid, S. Z. A., Rahman, A. R. A., \& Ismail, W. K. W. (2011). Management accounting systems in Islamic and conventional financial institutions in Malaysia. Journal of Islamic Accounting and Business Research, 2(2), 153-176. doi: 10.1108/17590811111170557

22. Sardar, Z. (1998). Technology: from Sweet Virtuosity to Domestic Self-Reliance (A. Priyono, Trans.). In A. Priyono (Ed.), Jihad Intelektual: Merumuskan ParameterParameter Sains Islam (pp. 133-155). Surabaya: Risalah Gusti.

23. Shank, J. K., \& Govindarajan, V. (2000). Strategic Cost Management and the Value Chain. In J. M. Reeve (Ed.), Reading and Issues in Cost Management (2 ed., pp. 185214). Canada: South-Western College Publishing.

24. Shiddieq, U. M. D. f. (2008). Ibadah Mahdhah \& Ghairu Mahdhah. Retrieved from http://umayonline.wordpress.com/2008/09/15/ibadah-mahdhah-ghairu-mhadhah/

25. Sonhaji. (2016). Rerangka Konseptual Akuntansi Manajemen Syariah: Sebuah Gagasan Awal. In Fordebi \& Adesy (Eds.), Akuntansi Syariah: Seri Konsep dan Aplikasi Ekonomi dan Bisnis Islam (1 ed., pp. 150-174). Jakarta: Rajawali Pres.

26. Syamsul. (2012). Konsep Maslahah Dalam Hukum Islam Retrieved 28 September at 12.05 , 2014, from http://syamsuljosh.blogspot.com/2012/06/konsep-maslahah-dalamhukum-islam.html

27. Syaputra, E. et al (2014). Maslahah as an Islamic Source and its Application in Financial Transactions. Quest Journals: Journal of Research in Humanities and Social Science Volume, 2(5), 66-71.

28. Triyuwono, I. (2000). Organisasi dan Akuntansi Syari'ah. Yogyakarta: LKiS.

29. Triyuwono, I. (2004). The Islamic Perspective on the Construction of Accounting Discipline. Gadjah Mada International Journal of Business, 6(1), 131-149.

30. Triyuwono, I. (2006). Akuntansi Syari'ah: Menuju Puncak Kesadaran Ketuhanan Manunggaling Kawulo-Gusti. Pidato Pengukuhan Guru Besar Akuntansi Syari'ah di Gedung PPI Universitas Brawijaya. Malang.

31. Triyuwono, I. (2010). "Mata Ketiga": Sé Laén, Sang Pembebas Sistem Pendidikan Tinggi Akuntansi. Jurnal Akuntansi Multiparadigma, 1(1).

32. Triyuwono, I. (2012). So, What is Sharia Accounting? Paper presented at the The Fourth UB International Consortium on Accounting, University of Brawijaya Malang.

33. Triyuwono, I. (2015). Akuntansi Malangan: Salam Satu Jiwa dan Konsep Kinerja Klub Sepak Bola. Jurnal Akuntansi Multiparadigma, 6(2), 175-340.

34. Velayutham, S. (2014). "Conventional" accounting vs "Islamic" accounting: the debate revisited. Journal of Islamic Accounting and Business Research, 5(2), 126-141. doi: DOI 10.1108/JIABR-05-2012-0026

35. Waweru, N. M. (2010). The origin and evolution of management accounting: a review of the theoretical framework. Problems and Perspectives in Management 8(3), 165-181. 